\title{
Rehabilitation of a Child with History of Multiple Natal Teeth and Oligodontia in the Permanent Dentition
}

Reabilitação de Paciente Infantil com Múltiplos Dentes Natais e Oligodontia na Dentição Permanente

\author{
Patricia Fernanda Dias ${ }^{1}$, Lizandra Ferrari Guimarães ${ }^{2}$, Ana Lúcia de Souza Freire Sanchez ${ }^{3}$, Laura Guimarães Primo ${ }^{4}$
}

\begin{abstract}
The objective of the present article is to report an uncommon case of a boy with history of 11 natal lost teeth, all belonging to the normal series of primary dentition, associated with absence of up to 21 permanent tooth germs. Such a condition resulted in the necessity for oral rehabilitation. Partial removable prostheses were used as a choice of treatment, and the patient will have to be constantly followed up so that new treatment approaches can be performed according to the patient's development.
\end{abstract}

Keywords: Child; Natal Teeth; Anodontia; Mouth Rehabilitation; Denture; Partial; Removable.

\section{Resumo}

O objetivo do presente artigo é reportar um caso incomum de um paciente infantil com história de 11 dentes natais extraídos, todos da série normal da dentição decídua, além de ausência de 21 germes da dentição permanente. Essa condição tornou necessária a reabilitação protética deste paciente. $O$ tratamento de escolha foi a utilização de próteses parciais removíveis, e o paciente terá que ser constantemente acompanhado para que, conforme seu crescimento, novas alternativas de tratamento sejam utilizadas.

Palavras-chave: Criança; Dentes natais; Anodontia; Reabilitação bucal; Prótese parcial removível.
${ }^{1}$ Especialista e Mestre em Odontopediatria, Departamento de Odontopediatria e Ortodontia, Faculdade de Odontologia, Universidade Federal do Rio de Janeiro

${ }^{2}$ Especialista e Mestre em Odontopediatria, Departamento de Odontopediatria e Ortodontia, Faculdade de Odontologia, Universidade Federal do Rio de Janeiro. Professora Substituta da Odontopediatria da Faculdade de Odontologia da Universidade Federal do Rio Grande do Sul

${ }^{3}$ Especialista em Prótese dentária e Mestre em Odontopediatria; Professora Adjunta, Departamento de Odontopediatria, Faculdade de Odontologia, Universidade Gama Filho(RJ)

${ }^{4}$ Professora Adjunta, Departamento de Odontopediatria e Ortodontia, Faculdade de Odontologia, Universidade Federal do Rio de Janeiro

Correspondência: Patricia Fernanda Dias

Endereço: Rua Caroen, 345 - CEP 21210-340, Rio de Janeiro - RJ, Brasil Fone: (21) 9758-4749

E-mail: patriciafernandadias@gmail.com

Data de Submissão: 30/06/2009

Data de Aceite: $11 / 03 / 2010$

\section{Introduction}

Natal teeth are those ones present in the oral cavity at birth (MASSLER; SAVARA, 1950), and they may belong to the primary dentition or may be a supernumerary one (RUSMAH, 1991). Although several aetiologies have been suggested (MASSLER; SAVARA, 1950.) in general such a condition is thought to be a familial phenomenon (MCDONALD; AVERY, 2000; SHAFER; HINE; LEVY, 1983).

Natal teeth, even those from the normal series, can also be extracted if breast feeding is affected (PRIMO et al., 1995), tooth mobility is excessive (PORTELA; DAMASCENO; PRIMO, 2004) or the baby's oral mucosa is lesioned (NIK-HUSSEIN, 1990). Therefore, the child is likely to need rehabilitation prosthetic intervention. Treatment alternatives include the following: fixed or removable space maintainers (MCDONALD; AVERY, 2000), fixed prostheses, overdentures, total prostheses, partial removable prostheses, and prostheses over implants (CALDO-TEIXEIRA; PUPPIN-RONTANI, 2003; TARJAN; GABRIS; ROZSA, 2005). Selection of the therapy will depend on the child's age, co-operation from the child, number of lost teeth, and presence or absence of germs of permanent succeeding teeth (BERGENDAL, 2001; KOTSIOMITI et al., 2000; MCDONALD; AVERY, 2000).

The term oligodontia is generally used when the development of six or more teeth didn't occurs (KOTSIOMITI et al., 2000), and such a condition may be related to family history, syndromes, traumas, infections, and severe intrauterine or endocrine disorders (KOTSIOMITI et al., 2000; MCDONALD; AVERY, 2000). A few reports on the relationship between natal teeth and absence of succeeding permanent teeth exist in the reviewed literature (BENNETT; RONK, 1980; MASATOMI; ABE; OOSHIMA, 1991; NEVILLE et al., 2002). In those cases exhibiting both developmental disturbances, the treatment of the child patient represents a challenge for the paediatric dentist because both constant follow-up and careful planning should be considered so that treatment can be adjusted to all phases of the child's development (BERGENDAL, 2001). 
As a result, the objective of the present report is to describe the prosthetic rehabilitation of a child patient with multiple natal lost teeth and up to 21 germs of absent permanent teeth.

\section{Case Report}

A Caucasian male infant has been followed up since 1month-old in the Department of Pediatric Dentistry of a public institution of superior education in

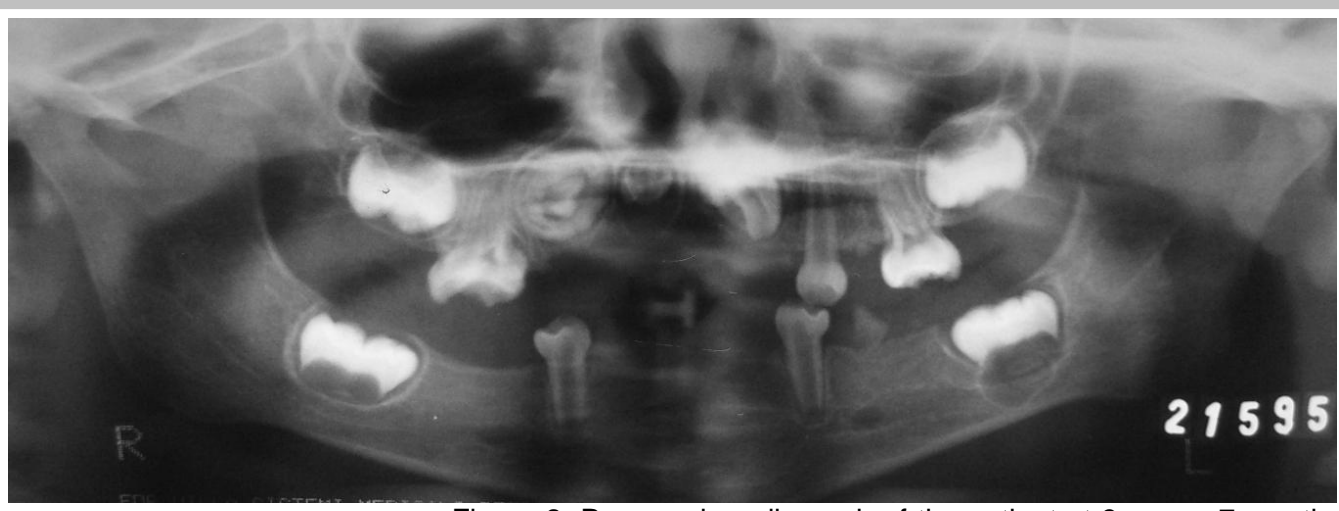
Rio de Janeiro, Brazil, because he presented 11 natal teeth belonging to the normal series of the primary dentition. Such dentition elements had been either exfoliated or extracted due to their excessive mobility (PORTELA; DAMASCENO; PRIMO, 2004). No relevant findings were found in the child's medical history, but the family history showed that the father and the paternal grandfather had natal teeth and the father had agenesis involving permanent teeth. On clinical examination no changes in skin, hair, eyes, ears or other body structure were observed as well.

The child was periodically followed up in order to observe his dentition development and instruct his caregiver about oral hygiene and diet. When the child was 3 years 7 months old, his parents complained of the aesthetic appearance, masticatory dysfunction and speech difficulties the child was facing, since only the primary maxillary second molars and left canine and mandibular canines were erupted. With the exception of the primary maxillary right second molar, which had hypoplasia with loss of dental structure, the other elements were found to be healthy (Figure 1). In that moment, the radiographic exam (Figure 2) showed a possibility absence of up to 21 germs of permanent teeth (not considering the third molars) and apparent malformation involving 3 germs in the antero-superior region. In order to restore shape, function, and aesthetics, the primary maxillary right second molar was reconstructed by using composite, and removable space maintainers were also prepared for upper and lower arches.

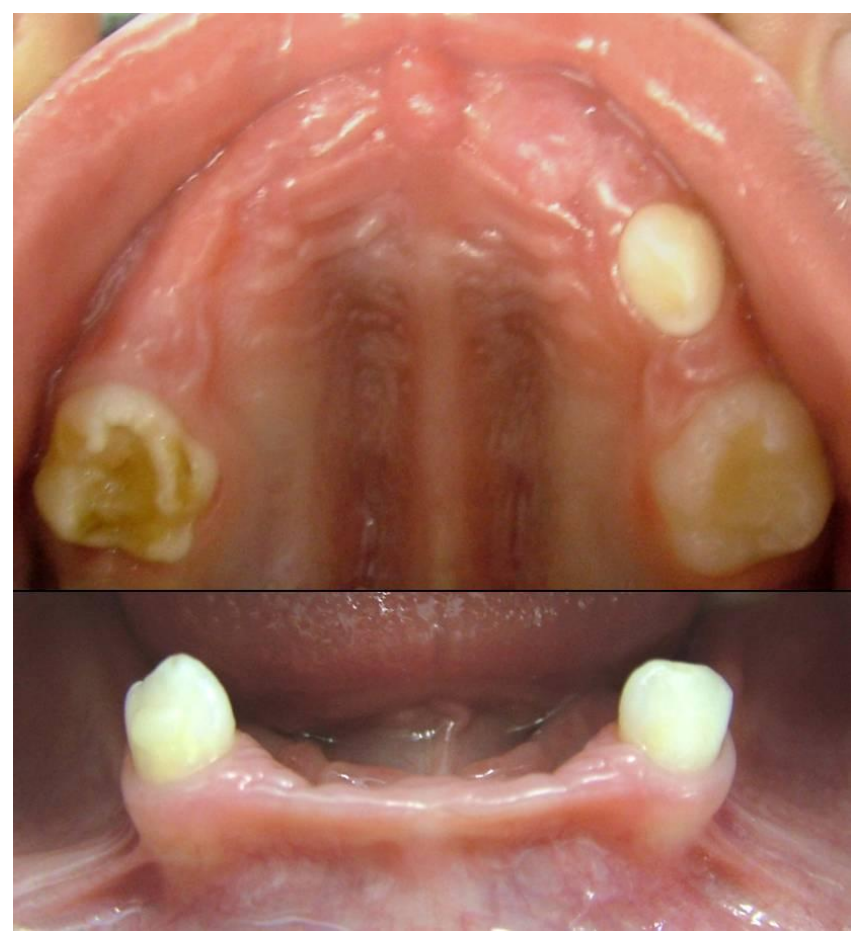

Figure 1. Clinical aspect at 3 years, 7 months old: (A) Superior arch (B) Inferior arch. 


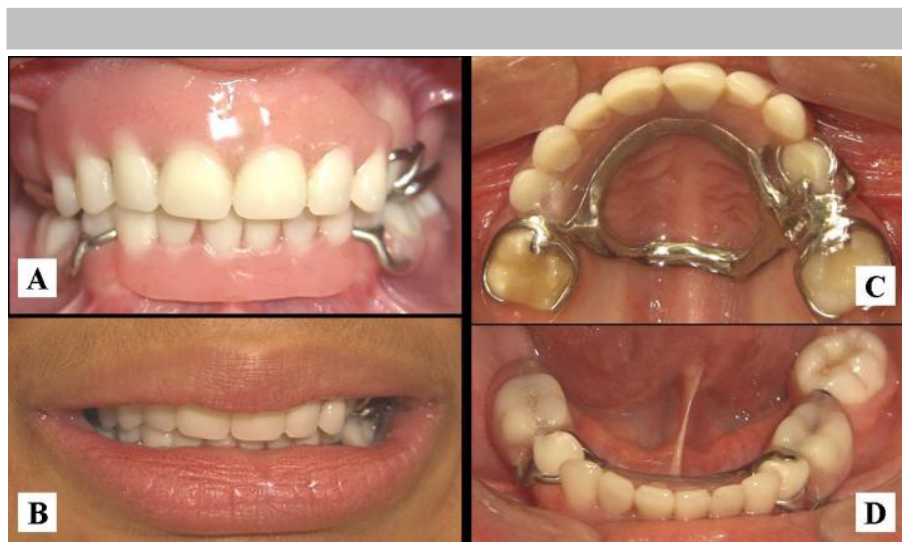

Figure 4. Six-month follow-up after installation of the prostheses. Frontal view of the prostheses: (A) intra-oral (B) extra-oral. Occlusal view of the prostheses: (C) upper (D) lower.

\section{Discussion}

Oligodontia involving permanent teeth can be associated with different local or systemic conditions (SHAFER; HINE; LEVY, 1983; NEVILLE et al., 2002), such as ectodermic dysplasia, which is the most common condition reported in the literature (BERGENDAL, 2001; KOTSIOMITI et al., 2000; TARJAN; GABRIS; ROZSA, 2005).

However, in the present case report, the patient did not present signs of such alterations and consequently the possible aetiology is likely to involve the family history. In addition, the condition described above is rare because besides the agenesis of up to 21 permanent teeth, there was a history of multiple natal teeth.

Bennett and Ronk (1980) reported a case of 2 neonatal teeth associated with absence of various germs of permanent teeth in a 4-year-old child without any family history or systemic disorder. In another case, also with unknown aetiology, Masatomi et al. (1991) described a history of a 22-day-old patient presenting 14 natal teeth, most with no permanent succeeding. Moreover, the succeeding elements existing in the antero-superior region were malformed, as in the present case. Kakarantza-Angelopoulou et al. (1993) also reported the presence of a malformed permanent maxillary incisor in a 6-year-old child who had 5 natal teeth at birth as well as the absence of several germs of permanent teeth on the radiographic examination. In addition to such alterations, in the present case the permanent mandibular left first molar had erupted when the child was 3 years 10 months old. A possible explanation for this fact is the tendency towards early eruption involving both dentitions, since the patient carried natal teeth belonging to the normal series of primary dentition.

In the present case, a removable space maintainer, which is a more inexpensive option, was chosen for initial treatment due to the lack of primary teeth, since the patient was co-operative and the caregivers motivated (MCDONALD; AVERY, 2000; DOMINGUEZ; AZNAR, 2004). Nevertheless, this treatment option failed because of the lack of retention due to the anatomy of primary teeth and the low strength of materials used in the confection of the appliances. Such a fact, in association with oligodontia involving the permanent dentition, led to the necessity of performing a new treatment planning. According to Bergendal (2001), the diagnosis of tooth agenesis should be carried out as early as possible to use growthadapted measures in the planning process.

Although fixed apparatuses are more suitable for long periods of space maintenance (QUDEIMAT; FAYLE, 1998), the reduced number of primary teeth did not allow the use of a fixed prosthesis. As the patient was too young, the use of prosthesis over implant was also contraindicated because of the inherent process of osseointegration, which causes the implants to fail in following the vertical dento-alveolar development and become submerged (WILLIAMS; TRAVESS; SANDY, 2004). In addition, children with missing teeth do not have sufficient amount of alveolar bone which makes the implants to be subjected to a greater risk of failures in comparison to more conservative prosthetic treatment (LO MUZIO et al., 2005). An overdenture would be a viable option only in the lower arch of the patient, for the remaining teeth might be used as additional support (CALDO-TEIXEIRA; PUPPIN-RONTANI, 2003).

Therefore, the cast metal prosthesis was chosen as a treatment option because of its better strength and retentiveness, which are properties the space maintainer made of steel wire and acrylic resin did not provide. Although such materials raise the treatment costs, this kind of prosthesis has greater durability and it is suitable in the face of several missing teeth, either primary or permanent. Tarjan et al. (2005) advice that prosthetic treatment for children should begin at the age of 3 years. Although caution concerning the risk of obstructing the growth should be take, transversal and sagittal dimensions of the dental arches remain unaltered between the ages of 3 and 5.5 years (BAUME, 1950), thus indicating the prostheses used in the present case because they should not interfere with growth and consequently remain adjusted for a longer period of time.

It should also be emphasised that the basis and technique for constructing prostheses for paediatric use are similar to those used for adults (TARJAN; GABRIS; ROZSA, 2005). Therefore, multidisciplinar interaction between paediatric dentist and prosthodontist is necessary so that the oral rehabilitation is well planned and successfully performed.

The main benefits regarding the prosthetic rehabilitation are restoration of the masticatory functions as well as improvement of speech and aesthetic appearance by replacing the missing teeth and re-establishing the occlusal vertical dimension (KOTSIOMITI et al., 2000; TARJAN; GABRIS; ROZSA, 2005). Depending on the patient's age, the aesthetic imperfection may result in severe psychosocial disorder (CALDO-TEIXEIRA; PUPPIN-RONTANI 2003). In the present case, for instance, aesthetics was the main complaint made by the parents, whereas the child had difficulties in swallowing solid food. Such problems were solved after prosthesis installation. The satisfaction expressed by both child and parents can be verified during the evaluation appointments, where very important measures are taken to keep the satisfactory treatment outcome, namely: co-operation on the part of the child regarding the use of prostheses, care on the part of the parents regarding oral hygiene, and adhesion to treatment (DOMINGUEZ; AZNAR, 2004).

The success achieved by the therapy employed in the present case suggests that this is a good option for oral rehabilitation of child patients. However, such a treatment is not thought to be conclusive, since the parents should be instructed and the child followed up until growth is complete; after that, a definitive treatment could be implemented.

\section{* What this case report adds:}

This case report describes an uncommon relationship between natal teeth and absence of succeeding permanent teeth with great dimensions because the child presented 11 natal teeth belonging to the normal series of the primary dentition that was lost and apparently absence of up to 21 germs of permanent teeth. In these cases exhibiting both developmental disturbances, the treatment represents a challenge for the dentist because both constant follow-up and careful planning should be considered so that the oral functions could be re-established.

Moreover, it describes the treatment of the patient with an advice uncommonly used in children, with partial removable prostheses with cast metal structure. These prostheses were chosen because of its better strength, retentiveness and durability. On this way, it was the option capable of restoration of the masticatory functions as well as improvement of speech and aesthetic appearance, considering the cost-benefit. Consequently, both patient and his parents were satisfied with the outcome provided by the therapy employed.

This paper also emphasizes that the basis and technique for constructing prostheses for paediatric use are similar to those used for adults. Therefore, multidisciplinar interaction between 
paediatric dentist and prosthodontist is necessary so that the ora rehabilitation is well planned and successfully performed

\section{References}

BAUME, L. J. Physiological tooth migration and its significance for development of occlusion. The biogenetic course of the deciduous dentition. J. Dent. Res., Chicago, v. 29, no. 4, p. 123-132, Aug. 1950.

BENNETT, C. G.; RONK, S. L. Congenitally missing primary teeth: report of case. J. Dent. Child., Chicago, v. 47, no. 5, p. 346-348, Sept./Oct. 1980.

BERGENDAL, B. Prosthetic habilitation of a young patient with hypohidrotic ectodermal dysplasia and oligodontia: a case report of 20 years of treatment. Int. J. Prosthodont., Lombard, v. 14, no. 5, p. 471-479, Sept./Oct. 2001.

CALDO-TEIXEIRA, A. S.; PUPPIN-RONTANI, R. M. Management of severe partial hipodontia: case report. J. Clin. Pediatr. Dent., Birmingham, v. 27, no. 2, p. 133-136, Winter 2003.

DOMINGUEZ, A.; AZNAR, T. Removable prostheses for preschoo children: report of two cases. Quintessence Int., Berlin, v. 35, no. 5, p. 397-400, May 2004

KAKARANTZA-ANGELOPOULOU, E.; PAPAGIANNOULIS, L.; NIKAS, G. Multiple immature natal teeth in a newborn. J. Clin. Pediatr. Dent., Birmingham, v. 17, no. 3, p. 157-162, 1993.

KOTSIOMITI, E. et al. Removable prosthodontic treatment for the primary and mixed dentition. J. Clin. Pediatr. Dent., Birmingham, v. 24, no. 2, p. 83-89, Winter 2000.

LO MUZIO, L. et al. Prosthetic rehabilitation of a child affected from anhydrotic ectodermal dysplasia: a case report. J. Contemp. Dent. Pract., Chicago, v. 6, no. 3, p. 120-126, Aug. 2005.

MASATOMI, Y.; ABE, K.; OOSHIMA, T. Unusual multiple natal teeth: case report. Pediatr. Dent., Chicago, v. 13, no. 3, p. 170-172, May/June 1991.

MASSLER, M.; SAVARA, B. S. Natal and neonatal teeth: a review of twenty-four cases report in the literature. J. Pediatr., St. Louis, v. 36, no. 3, p. 349-359, Mar. 1950

MCDONALD, R. E.; AVERY, D. R. Dentistry for the child and adolescent. 7th ed. Philadelphia: CV Mosby, 2000.

NEVILLE, B. W. et al. Abnormalities of teeth. In: Oral and maxillofacial pathology. 2nd ed. Philadelphia: WB Saunders; 2002. p. 49-106.

NIK-HUSSEIN, N. N. Natal and neonatal teeth. J. Pedod., Birmingham, v. 14, no. 2, p. 110-112, Winter 1990.

PORTELA, M. B.; DAMASCENO, L.; PRIMO, L. G. Unusual case of multiple natal teeth. J. Clin. Pediatr. Dent., Birmingham, v. 29, no. 1, p. 37-40, Fall 2004.

PRIMO, L. G. et al. Interruption of breast feeding caused by the presence of neonatal teeth. Braz. Dent. J., Ribeirão Preto, v. 6, no. 2, p. 137-142, 1995.

QUDEIMAT, M. A.; FAYLE, S. A. The longevity of space maintainers: a retrospective study. Pediatr. Dent., Chicago, v. 20, no. 4, p. 267-272, June/Aug. 1998.
RUSMAH, M. Natal and neonatal teeth: a clinical and histological study. J. Clin. Pediatr. Dent., Birmingham, v. 15, no. 4, p. 251-253, Summer 1991.

SHAFER, W. G.; HINE, M. K; LEVY, B. M. A Textbook of oral pathology. 4th ed. Philadelphia: WB Saunders, 1983.

TARJAN, I.; GABRIS, K.; ROZSA, N. Early prosthetic treatment of patients with ectodermal dysplasia: a clinical report. J. Prosthet. Dent., St Louis, v. 93, no. 5, p. 419-424, May 2005.

WILLIAMS, P.; TRAVESS, $\mathrm{H}_{\text {; }}$; SANDY, J. The use of osseointegrated implants in orthodontic patients: I. Implants and their use in children. Dent. Update., London, v. 31, no. 5, p. 287290, June 2004. 